\title{
PENGARUH BIAYA PEMASARAN TERHADAP VOLUME PENJUALAN INDUSTRI KERAJINAN TIKAR MENDONG MEKAR PUTRA TASIKMALAYA
}

\author{
Yusup Kurnia \\ Program Studi Teknik Industri, Fakultas Teknik, Universitas Galuh Ciamis \\ email : yusupkurnia979@gmail.com
}

\begin{abstract}
Marketing has a very important role to reach the market as much as possible. Marketing activities are at the fore front of earning revenue. The study aims to determine whether the marketing costs incurred by the handicraft industry Tikar Mendong Putra Tasikmalaya impact on increased sales or not. Methods of data collection is done by documentation, interview, and observation, while data analysis technique using correlation coefficient, coefficient of determination, regression, and t-test. The results indicate that marketing costs incurred in 2011-2015 is Rp. 183.175.000, while the sales volume reached is Rp. 184.978.000. Based on the results of testing the correlation of marketing costs with sales volume is known at 0.929 , where the value shows a meaningful relationship and very strong, while the test results coefficient determination known that marketing costs have an effect of $86 \%$ of sales volume, and the remaining 14\% influenced by other factors which is not researched. The result of regression testing is known $(Y)=$ $10787676,29+0.72 X$, where marketing cost give positive contribution to sales volume equal to 0.72 unit, and result of hypothesis $t_{\text {count }}$ is 4.35 value bigger than $t_{\text {table }}$ value at significance level 0.05 (4.34> 2.57). Thus the research hypothesis can be accepted, meaning that marketing costs have a positive effect on sales volume.
\end{abstract}

Keywords: Marketing, Sales Volume

\section{PENDAHULUAN}

\subsection{Latar Belakang}

Industri Kecil dan Menengah (IKM) merupakan sumber potensi dalam kegiatan ekonomi nasional. Pemerintah pun menyadari bahwa sektor Industri Kecil dan Menengah (IKM) merupakan salah satu pilar penting dalam pembangunan ekonomi Indonesia. Sehingga Industri Kecil dan Menengah (IKM) sering dikaitkan dengan upaya-upaya pemerintah untuk mengurangi pengangguran, memerangi kemiskinan dan pemerataan pendapatan.

Perusahaan Tikar Mendong Mekar Putra merupakan salah satu IKM yang mencoba mengimplementasikan manajemen pemasaran untuk meningkatkan volume penjualan produknya. Hal ini ditandai oleh dibentuknya bagian pemasaran sebagai bagian tersendiri dari struktur organisasi dan dialokasikan dana khusus untuk pemasaran. Berdasarkan uraian diatas, maka masalah yang akan diteliti adalah: Berapa biaya pemasaran yang dikeluarkan, berapa besar penjualan yang telah dicapai, dansejauhmana pengaruh biaya pemasaran terhadap volume penjualan Industri Tikar Mendong Mekar Putra?

Adapun tujuan penelitian ini adalah : Untuk mengetahui besarnya biaya pemasaran yang dikeluarkan oleh perusahaan, untuk mengetahui besarnya volume penjualan yang dicapai oleh perusahaan dan untuk mengetahui pengaruh biaya pemasaran terhadap volume penjualan di Industri Tikar Mendong Mekar Putra.

\subsection{Tinjauan Pustaka Pengertian Biaya}

a. Hendri Simamora (1999: 35), menyatakan bahwa biaya adalah pengorbanan yang dilakukan untuk memperoleh barang atau jasa.

b. Mulyadi (1999: 8), menyatakan bahwa biaya dalam arti luas adalah pengorbanan sember ekonomi yang diukur satuan uang, yang telah terjadi atau kemungkinan terjadi untuk tujuan tertentu.

c. J.B Hecker (1991: 453), menyatakan bahwa biaya dapat didefinisikan sebagai jumlah dari semua pengeluaran dan beban yang ditetapkan, yang timbul secara langsung atau tidak langsung untuk mempersiapkan suatu barang atau bahan dalam kondisi dan lokasi sebagaimana adanya.

Berdasarkan definisi diatas, dapat disimpulkan bahwa:

1. Biaya merupakan pengorbanan sumber ekonomi.

2. Biaya diukur dalam satuan uang.

3. Pengorbanan untuk tujuan tertentu.

Yang telah terjadi atau potensial yang akan terjadi 


\section{Pengertian Pemasaran}

Philip Kotler (1997: 8), mengungkapkan definisi pemasaran sebagai suatu proses sosial dan manajerial yang didalamnya individu dan kelompok mendapatkan apa yang mereka butuhkan dan inginkan dengan menciptakan, menawarkan dan mempertukarkan produk yang bernilai dengan pihak lain.

Definisi pemasaran yang lain dikemukakan oleh Alex S. Nitisemito (1991: 13) dimana pemasaran adalah semua kegiatan yang bertujuan memperlancar arus barang dan jasa dari produsen secara efisien dengan maksud untuk menciptakan permintaan efektif.

Sedangkan menurut J.E Jerome McCharty (1993: 9) pemasaran adalah pelaksanaan sejumlah kegiatan yang dilakukan untuk mencapai tujuan organisasi dengan mengantisipasi kebutuhan pelanggan serta mengarahkan arus barang dan jasa yang dibutuhkan dari produsen kepada pelanggan.

Berdasarkan definisi yang dikemukakan oleh ahli pemasaran diatas, dapat disimpulkan bahwa pemasaran berkaitan dengan:

1. Pemasaran merupakan pusat dari sebuah kegiatan bisnis.

2. Pemasaran merupakan upaya mempercepat hasil produksi sampai konsumen.

3. Pemasaran merupakan usaha untuk mencapai penjualan dari perusahaan.

\section{Fungsi Pemasaran}

Setelah mendefinisikan hasil pemasaran, selanjutnya akan dikemukakan fungsi pemasaran yang merupakan titik puncak bagi perusahaan untuk menjual hasil produksinya.

Menurut Mulyadi (1999: 530) fungsi pemasaran digolongkan sebagai berikut:

1. Fungsi penjualan, terdiri atas kegiatan memenuhi pesanan yang diterima pelanggan.

2. Fungsi advertensi, terdiri atas kegiatan perancangan, pelaksanaan kegiatan melalui kegiatan advertensi dan promosi.

3. Fungsi pembungkusan dan pengiriman, terdiri dari kegiatan pembungkusan dan pengiriman produk ke konsumen.

4. Fungsi kredit dan penagihan, terdiri atas kegiatan pemantauan kemampuan keuangan pembeli dan penagihan piutang dari para pembeli.
5. Fungsi akuntansi pemasaran, terdiri atas kegiatan pembukuan faktur dan catatan akuntansi penjualan.

\section{Pengertian Biaya Pemasaran}

Dalam kegiatan pemasaran, setiap perusahaan khususnya pihak manajemen perlu memperhatikan tentang biaya-biaya yang dikeluarkan dalam memasarkan produknya.

Berikut ini pengertian mengenai biaya pemasaran dari beberapa ahli, diantaranya menurut Mulyadi (1999: 529), biaya pemasaran dibagi menjadi dua, dalam arti sempit dan dalam arti luas. Dalam arti sempit biaya produksi yaitu biaya-biaya yang dikeluarkan untuk menjual barang produksi ke pasar. Dalam arti luas, meliputi semua biaya yang terjadi pada saat produk diproduksi dan disimpan di gudang sampai produk tersebut kembali dalam bentuk uang tunai.

Sedangkan menurut Hendri Simamora (1999: 36), biaya pemasaran meliputi biaya yang dikeluarkan dalam mendapatkan pesanan pelanggan dan menyerahkan hasil produk tersebut ke pelanggan.

\section{Pengertian Penjualan}

Penjualan adalah jumlah yang dibebankan kepada pembeli atas barang yang dijual dalam suatu periode.

\section{Volume penjualan}

Para manajer harus bisa menganalisis produktivitas perusahaannya sebelum memasarkan hasil produksinya. Dalam pemasaran banyak sekali faktor yang mempengaruhi terhadap volume penjualan.

Banyak pesanan dari pembeli sangat erat hubungannya dengan menguntungkan tidaknya perusahaan. Oleh karena itu, perusahaan harus menentukan nilai jumlah rupiah atau kuantitas minimum dalam setiap produknya.

Berikut ini pengertian dari volume penjualan:

1. Mulayadi (1999: 239), volume penjualan adalah jumlah unit produksi yang dapat dijual.

2. JosepH P. Guiltinan (1994: 130), mendefinisikan volume penjualan adalah besarnya kapasitas produk atau jasa yang dijual. 
3. J.B. Heckert (1991: 248), volume penjualan adalah penjualan yang dinyatakan dalam jumlah penjualan banyaknya satuan fisik atau jumlah yang yang harus dicapai.

Dari ketiga pendapat diatas, dapat disimpulkan bahwa penjualan merupakan jumlah barang yang diproduksi dinyatakan dalam unit atau satuan uang yang terjual kepada konsumen.

Dalam menjual produksi perusahaan dapat menggunakan beberapa metode penjualan. Ada 4 sistem penjualan. (Guiltinan, 1994: 307), yaitu:

1. Sistem tanggapan langsung

Sistem ini merupakan program penggabungan antara program-program periklanan, penjualan tatap muka, dan promosi penjualan.

2. Sistem penjualan tatap muka langsung

Sistem in disampaikan oleh para wiraniaga atau oleh perwakilan perusahaan yaitu orang yang bertindak sebagai agen penjualan yang bertugas untuk perusahaan. Para wiraniaga ini memusatkan kegiatan dengan memecahkan masalah para pelanggan mengenai pembelian produk dengan mendemonstrasikan bagaimana suatu produk dapat digunakan dengan kebutuhan pelanggan.

3. Sistem penjualan perdagangan

Bila organisasi menggunakan jasa pedagang besar atau pengecer untuk mendistribusikan produk kepelanggan akhir. Kemudian armada wiraniaga memastikan distributor bersedia dan mampu mendukung strategi pemasaran. Armada wiraniaga ini bertugas memperhatikan kepada distributor mengenai manfaat dari kebijakankebijakan spesifik yang memperkuat penjualan dari perusahaan.

4. Sistem penjualan misionari

Penjualan ini merupakan kegiatan yang memperkuat penjualan distributor yang lebih diarahkan kepada pembelian akhir.

\section{Pengaruh Biaya Pemasaran terhadap Volume Penjualan}

Biaya pemasaran digunakan oleh perusahaan untuk memperlancar penyaluran atau penjualan produk dari produsen ke konsumen. Perusahaan dituntut seefektif dan seefisien mungkin karena kegiatan pemasaran akan mempengaruhi volume penjualan.

Biaya yang dikeluarkan perusahaan untuk pemasaran berguna untuk menjual atau memperkenalkan produknya kepada para konsumen. Hal ini menunjukan bahwa terdapat pengaruh antara biaya pemasaran dengan volume penjualan.

Besarnya volume penjualan sangat bergantung pada sistem pemasaran yang diterapkan oleh perusahaan dan luas tidaknya peluang pasar untuk menjual produknya. Dengan demikian besarnya biaya pemasaran yang dikeluarkan akan berpengaruh terhadap besarnya volume penjualan.

Jika ingin menambah biaya pemasarannya, maka harus diikuti pula oleh kenaikan volume penjualan produknya, karena hal tersebut untuk menghadapi persaingan dengan perusahaan sejenis dan mendapatkan pelanggan baru.

\section{METODE PENELITIAN}

Metode penelitian merupakan cara utama yang dipergunakan untuk mencapai tujuan penelitian, dengan cara menguji serangkaian hipotesis dengan menggunakan teknik dan alat-alat tertentu. (Winamo, 1994; 13 1). Metode yang dipergunakan dalam penelitian ini adalah metode deskriptif. Metode deskriptif adalah metode yang dipergunakan untuk pemecahan masalah yang ada pada masa sekarang dan pelaksanaannya tidak terbatas pada penyusunan dan pengumpulan data melainkan meliputi analisis interpretasi data. (Surakhmad, 1994).

\section{Flow Chart}

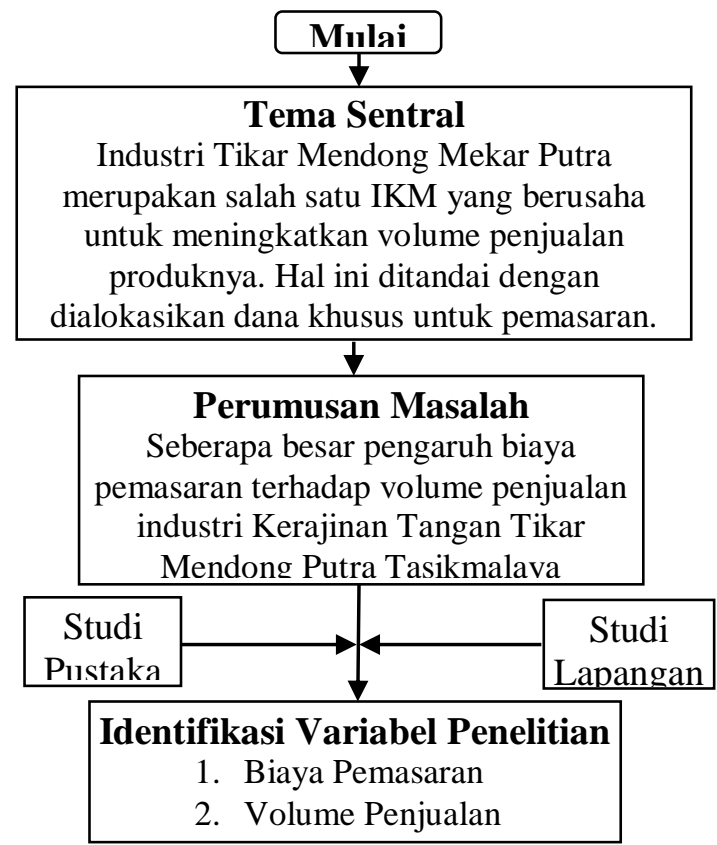

Computer Science | Industrial Engineering |Mechanic Engineering |Civil Engineering 


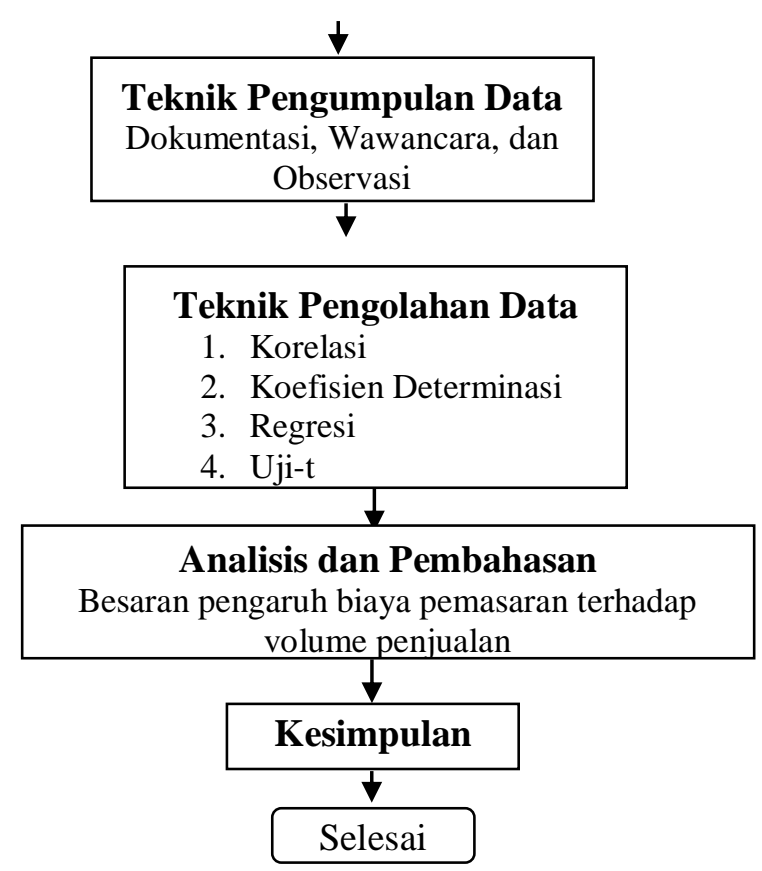

Gambar 1. Flow Chart

\section{Variabel Penelitian}

Biaya pernasaran sebagai variabel bebas independen atau variabel $\mathrm{X}$ dan volume penjualan sebagai variabel terkait dependen variabel atau variabel $\mathrm{Y}$, kemudian menganalisa seberapa besar hubungan dari variabel bebas $(\mathrm{X})$ terhadap variabel terikat $(\mathrm{Y})$.

Tabel 1. Variabel Penelitian (Operasional Variabel)

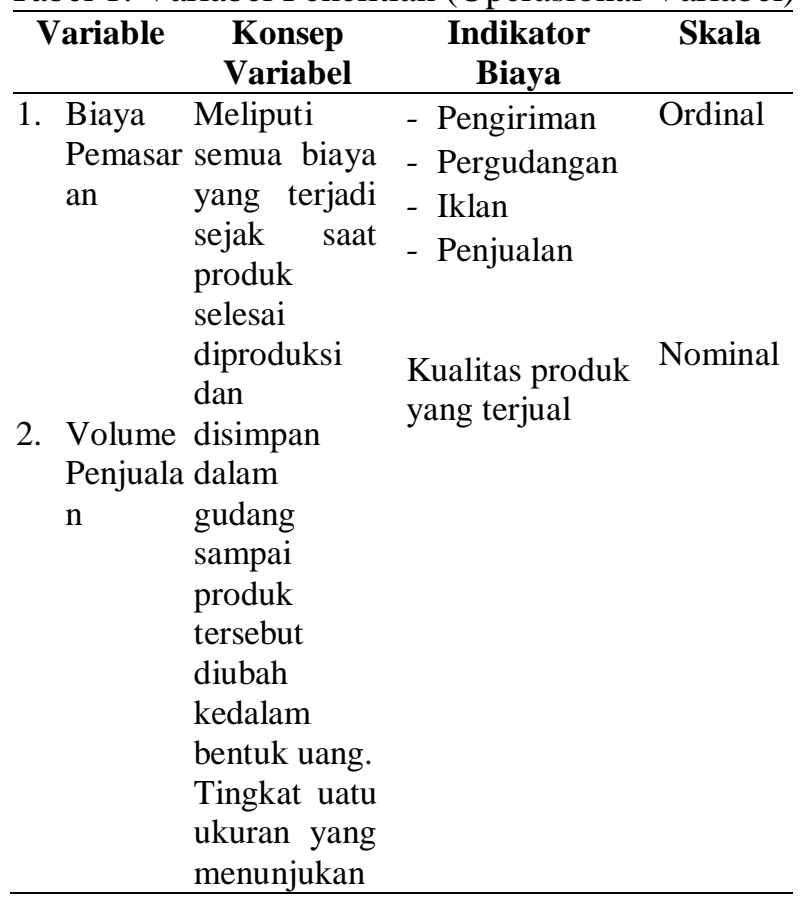

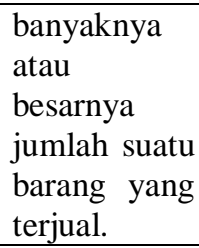

Jenis data yang diperlukan dalam penelitian adalah:
a. Data Primer
b. Data Sekunder

Metode atau teknik pengumpulan data yang digunakan dalam penelitian ini adalah dengan cara sebagai berikut:

a. Dokumentasi, metode pengumpulan data yang diperoleh dari catatan-catatan atau sumber tertulis dari objek penelitian yang dapat dipercaya kebenarannya.

b. Wawancara, adalah suatu metode pengumpulan data dengan cara tanya jawab dengan pernimpin perusahaan yang berhubungan dengan masalah yang diteliti.

c. Observasi, adalah suatu metode pengumpulan data dengan cara penelitian langsung di lokasi.

\section{Pengolahan Data}

a. Analisis korelasi product moment

$$
\mathrm{r}=\frac{n \sum X Y-\left(\sum X\right)\left(\sum Y\right)}{\sqrt{\left\{\left(n \sum X^{2}\right)-\left(\sum X^{2}\right)\right\}\left\{\left(n \sum Y^{2}\right)-\left(\sum Y^{2}\right)\right\}}}
$$

Dimana: $\mathrm{r}=$ Koefisien korelasi yang dicari

$\mathrm{X}=$ Variabel independen

$\mathrm{Y}=$ Variabel dependen

$\mathrm{n}=$ Jumlah tahun perputaran

Selanjutnya untuk mengetahui besarnya pengaruh variabel biaya pemasaran terhadap variabel volume penjualan adalah dengan rumus :

Koefisien Determinasi

$$
\mathrm{KD}=\mathrm{r}^{2} \times 100 \%
$$

Koefisien non Determinasi

$$
\mathrm{KnD}=\left(\mathrm{I}-\mathrm{r}^{2}\right) \times 100 \%
$$

b. Regresi

Untuk mengetahui pengaruh diantara dua variabel, sehingga dari pengaruh tesebut dapat menaksir variabel yang satu apabila harga 
variabel lainnya diketahui, digunakan rumus regresi linier sederhana.

Rumus regresi : $\mathrm{Y}=\mathrm{a}+\mathrm{bx}$

Dengan nilai a dan $b$ dapat dicari dengan rumus:

$$
\begin{aligned}
& a=\frac{\left(\sum Y\right)\left(\sum X^{2}\right)-\left(\sum X\right)\left(\sum X Y\right)}{n \sum X^{2}\left(\sum X\right)^{2}} \\
& b=\frac{n \sum X Y-\left(\sum X\right)\left(\sum Y\right)}{n \sum X^{2}-\left(\sum X\right)^{2}}
\end{aligned}
$$

Dimana: $\mathrm{Y}=$ Nilai taksiran hasil penjualan

$\mathrm{X}=$ Biaya pemasaran

$\mathrm{a}=$ Nilai taksiran penj ualan yang dapat dicapai $\mathrm{j}$ ika perusahaan tidak mengeluarkan biaya pemasaran $\mathrm{X}=0$.

$\mathrm{b}=$ Koefisien regresi yaitu suatu bilangan yang menunjukan pengaruh biaya pemasaran terhadap peningkatan volume penjualan.

$\mathrm{N}=$ Waktu

c. Teknik pengujian hipotesis

Untuk pengujian hipotesis digunakan uji t, dengan rumus sebagai berikut:

$$
t=\frac{r \sqrt{n-2}}{\sqrt{n-r^{2}}}
$$

Dimana: $t=t_{\text {hitung }}$

$r$ = Koefisien yang dihitung

$\mathrm{n}$ = Banyaknya data

Membuat keputusan terhadap hipotesis:

Terima Ho jika $t_{\text {hitung }} \leq t_{\text {tabel }}$

Terima Ha jika $t_{\text {hitung }} \geq t_{\text {tabel }}$

\section{Teknik Analisis Data}

Analisis secara deskriptif, yaitu dengan langkah-langkah sebagai berikut:

a. Menganalisis secara deskriptif tentang biaya pemasaran yang dilakukan oleh perusahaan. Dalam analisis ini peneliti akan menganalisis tentang indikator-indikator dari biaya pemasaran yaitu dilihat berdasarkan data biaya pemasaran perusahaan.

b. Mendeskripsikan volume penjualan perkembangan jumlah volume penjualan selama lima tahun, yaitu dari tahun 2011 sampai tahun 2015 sehingga dapat disimpulkan bahwa apakah volume penjualan mengalami peningkatan atau penurunan.

c. Untuk mengetahui dan menganalisis pengaruh biaya pemasaran dengan volume penjualan dengan cara membandingkan antara hasil analisis biaya pemasaran dengan volume penjualan sehingga dapat disimpulkan jika biaya pemasaran dijalankan dengan baik, maka penjualan akan meningkat.

d. Kesimpulan yang dapat diambil adalah biaya pemasaran akan mempengaruhi volume penjualan perusahaan, atau pengaruh biaya pemasaran dengan volume penjualan mempunyai hubungan yang positif.

\section{HASIL DAN PEMBAHASAN} Penetapan Harga Jual

Kebijakan perusahaan dalam mempertimbangkan perubahan harga dilakukan atas dasar hal-hal sebagai berikut:

a. Menaikan Harga

Besar kecilnya penetapan harga dengan volume penjualan tergantung pada harga yang ditetapkan perusahaan yang diterima konsumen, kemudian harga yang ditetapkan berpengaruh positif maka dapat meningkatkan volume penjualan dan tercapainya tujuan kebijakan penetapan harga yang diharapkan.

b. Menurunkan Harga

Penurunan harga disebakan karena kelebiahan kapasitas, sehingga produk yang sudah lama harga jualnya dikurangi.

Ada tiga yang harus dihadapi dalam penetapan harga, yaitu:

a. Perusahaan meninjau kembali harga yang telah ditetapkan sehubungan dengan adanya perubahan permintaan.

b. Perusahaan harus dapat menetapkan harga yang optimal.

c. Dalam penetapan harga, harus mempertimbangkan biaya produksi, biaya penelitian, dan biaya pemasaran. 
Tabel 2. Harga Jual Produk

\begin{tabular}{lll}
\hline \multicolumn{1}{c}{ Uraian } & \multicolumn{1}{c}{$\begin{array}{c}\text { Perlembar } \\
(\mathbf{R p})\end{array}$} & $\begin{array}{c}\text { Perpak } \\
(\mathbf{R p )})\end{array}$ \\
\hline Biaya Produksi & 19.500 & 390.000 \\
\hline Laba & 5.00 & 100.000 \\
\hline Harga Jual & 24.500 & 490.000 \\
\hline
\end{tabular}

Data Biaya Penjualan, Pergudangan, Pengiriman, dan Advertensi Kerajinan Tikar Mendong "MEKAR PUTRA"

Tabel 3. Biaya Penjualan, Pergudangan, Pengiriman, dan Advertensi Tahun 2011 - 2015

\begin{tabular}{lr}
\multicolumn{1}{c}{ Biaya } & $\begin{array}{c}\text { Biaya Pemasaran } \\
\text { (Rp) }\end{array}$ \\
\hline Penjualan & 62.600 .000 \\
\hline Pergudangan & 64.200 .000 \\
\hline Pengiriman & 48.200 .000 \\
\hline Advertensi & 8.175 .000 \\
\hline Jumlah & 183.175 .000 \\
\hline
\end{tabular}

Data Biaya Pemasaran Industri Kerajinan Tikar Mendong "MEKAR PUTRA"

Tabel 4. Biaya Pemasaran Tahun 2011 - 2015

\begin{tabular}{cr}
\hline Tahun & $\begin{array}{c}\text { Biaya Pemasaran } \\
(\mathbf{R p})\end{array}$ \\
\hline 2011 & 33.300 .000 \\
\hline 2012 & 34.300 .000 \\
\hline 2013 & 34.925 .000 \\
\hline 2014 & 39.350 .000 \\
\hline 2015 & 41.300 .000 \\
\hline
\end{tabular}

Data Penjualan Industri Kerajinan Tikar Mendong "MEKAR PUTRA"

Tabel 5. Volume Penjualan Tahun 2011 - 2015

\begin{tabular}{cr}
\hline Tahun & $\begin{array}{c}\text { Volume Penjualan } \\
\text { (Rp) }\end{array}$ \\
\hline 2011 & 33.320 .00 \\
\hline 2012 & 35.525 .000 \\
\hline 2013 & 37.240 .000 \\
\hline 2014 & 38.710 .000 \\
\hline 2015 & 40.180 .000 \\
\hline
\end{tabular}

Selanjutnya data yang telah tercantum digabungkan pada sebagai berikut:

Tabel 6. Biaya Pemasaran dan Volume Penjualan Tahun 2011 - 2015

\begin{tabular}{ccc} 
Tahun & $\begin{array}{c}\text { Biaya } \\
\text { Pemasaran } \\
(\mathbf{R p})\end{array}$ & $\begin{array}{c}\text { Biaya Penjualan } \\
(\mathbf{R p})\end{array}$ \\
\hline 2011 & 33.300 .000 & 33.320 .000 \\
\hline 2012 & 34.300 .000 & 35.525 .000 \\
\hline 2013 & 34.925 .000 & 37.240 .000 \\
\hline 2014 & 39.350 .000 & 38.710 .000 \\
\hline 2015 & 41.300 .000 & 40.180 .000 \\
\hline
\end{tabular}

Computer Science | Industrial Engineering | Mechanic Engineering | Civil Engineering 


\section{Pembahasan}

\section{Pengaruh Biaya Pemasaran terhadap Volume Penjualan Perusahaan}

Tabel 7. Harga Biaya Pemasaran dan Volume Penjualan

\begin{tabular}{cccccc}
\hline Tahun & $\begin{array}{c}\text { Biaya } \\
\text { Pemasaran } \\
(\mathbf{X})\end{array}$ & $\begin{array}{c}\text { Volume } \\
\text { Penjualan } \\
(\mathbf{Y})\end{array}$ & $\mathbf{X Y}$ & $\mathbf{X}^{\mathbf{2}}$ & $\mathbf{Y}^{\mathbf{2}}$ \\
\hline 2011 & 33.300 .000 & 33.320 .000 & $1,10956^{15}$ & $1,10889^{15}$ & $1,11022^{15}$ \\
\hline 2012 & 34.300 .000 & 35.525 .000 & $1,21851^{15}$ & $1,17649^{15}$ & $1,26203^{15}$ \\
\hline 2013 & 34.925 .000 & 37.240 .000 & $1,30061^{15}$ & $1,21976^{15}$ & $1,38682^{15}$ \\
\hline 2014 & 39.350 .000 & 38.710 .000 & $1,52324^{15}$ & $1,54842^{15}$ & $1,49846^{15}$ \\
\hline 2015 & 41.300 .300 & 40.180 .000 & $1,65943^{15}$ & $1,70569^{15}$ & $1,61443^{15}$ \\
\hline Jumlah & 183.175 .000 & 184.975 .000 & $6,81135^{15}$ & $6,75925^{15}$ & $6,87196^{15}$ \\
\hline
\end{tabular}

Untuk mengetahui seberapa besar hubungan antara biaya pemasaran terhadap volume penjualan dapat dicari dengan koefisien korelasi sebagai berikut:

$$
\begin{aligned}
& r \\
& r \\
& =\frac{n \sum X Y-}{\sqrt{\left\{n \sum X^{2}-\left(\sum X^{2}\right)\right\}}} \\
& \quad r=\frac{5 \times}{\sqrt{\left\{5 \times 6,75925^{15}\right.}} \\
& \quad r=\frac{1,7395^{14}}{1,81795} \\
& r=0,9294187 \\
& r=0.929
\end{aligned}
$$$$
=\frac{n \sum X Y-\left(\sum X\right)\left(\sum Y\right)}{\sqrt{\left\{n \sum X^{2}-\left(\sum X^{2}\right)\right\}\left\{n \sum Y^{2}-\left(\sum Y^{2}\right)\right\}}}
$$$$
=\frac{5 \times 6,81135^{15}-(183.175 .000)(184.975 .000)}{\sqrt{\left\{5 \times 6,75925^{15}-(183.175 .000)^{2}\right\}\left\{5 \times 6,87196^{15}-(184.975 .000)^{2}\right\}}}
$$

Dari hasil perhitungan diperoleh nilai korelasi sebesar 0.929, nilai tersebut setelah dikonsultasikan pada harga kritis product moment $\left(\mathrm{r}_{\text {tabel }}\right)$ dengan $\mathrm{n}=$ 5 pada taraf signifikansi 0.05 adalah sebesar 0.754 . Dengan demikian antara variabel biaya pemasaran dengan volume penjualan mempunyai hubungan yang signifikan karena nilai korelasi yang diperoleh $\left(r_{\text {hitung }}\right)$ lebih besar dari nilai signifikansi 0.05 (0.929 $>$ 0.754). Pada kriteria Guilford nilai tersebut berada pada rentang $0.90-1.00$, hal ini menunjukan bahwa hubungan biaya pemasaran dengan volume penjualan adalah sangat tinggi.

Sedangkan untuk mengetahui besarnya pengaruh biaya pemasaran terhadap volume penjualan dicari dengan koefisien determinasi sebagai berikut:

$$
\begin{aligned}
& K D=r^{2} \times 100 \% \\
& K D=0.929^{2} \times 100 \% \\
& K D=0,863041 \times 100 \% \\
& K D=86 \%
\end{aligned}
$$

Artinya pengaruh biaya pemasaran terhadap volume penjualan. pada perusahaan sebesar $86 \%$, dengan ini menujukan pengaruh biaya pemasaran terhadap volume penjualan adalah tinggi. pengaruh faktor lain di luar biaya pemasaran dapat dicari dengan rumus koefisien non determinasi, yaitu sebagai berikut:

$$
\begin{aligned}
& \text { NonD }=\left(I-r^{2}\right) \times 100 \% \\
& \text { Non } D=\left(I-0,929^{2}\right) \times 100 \% \\
& \text { Non } D=(1-0,863041) \times 100 \% \\
& \text { Non } D=0.136959 \times 100 \% \\
& \text { Non } D=14 \%
\end{aligned}
$$


Dari perhitungan di atas, diperoleh Non D sebesar $14 \%$ yang berarti pengaruh faktor lain di luar kegiatan seperti selera konsumen, persaingan pasar, kondisi perekonornian, kebijakan pemerintah berpengaruh terhadap volume penjualan.

\section{Persamaan Regresi}

Persamaan ini untuk menghitung volume penjualan dimana sudah diketahui dahulu biaya pemasarannya.

$$
\text { a }
$$$$
\begin{gathered}
=\frac{(184.975 .000)\left(6,75925^{15}\right)-(183.175 .000)\left(6,81135^{15}\right)}{5 \times 6,75925^{15}-(183.175 .000)^{2}} \\
a=\frac{(1,25029)^{24}-(1,24767)^{24}}{3,37962^{16}-3,35531^{16}} \\
a=\frac{2,62323^{14}}{2,4316^{14}} \\
b=\frac{n \sum X Y-\left(\sum X\right)\left(\sum Y\right)}{n \sum X^{2}-\left(\sum X\right)^{2}} \\
b \quad \frac{5 \times 6,81135^{15}-(183.175 .000)(184.975 .000)}{5 \times 6,75925^{15}-(183.175 .000)^{2}} \\
b=\frac{3,40568^{16}-3,38828^{16}}{3,37962^{16}-3,35531^{16}} \\
b=\frac{1,73954^{14}}{2,4316^{14}} \\
b=0,715390586
\end{gathered}
$$

Dari perhitungan di atas diperoleh persamaan regresi sebagai berikut:

$$
\mathrm{Y}=10787676,29+0,72 \mathrm{X}
$$

Nilai a konstanta sebesar 10787676,29 menunjukan apabila perusahaan tidak mengeluarkan biaya pemasaran, dengan kata lain biaya pemasaran yang dikeluarkan adalah sebesar Rp. 0,00 maka volume penjualan yang dicapai hanya sebesar 10787676,29 pak sedangkan nilai $x$ positif menunjukan biaya pemasaran akan berpengaruh pada peningkatan volume penjualan, misalnya nilai x Rp. 720.000 artinya bahwa perusahaan menambah atau mengurangi biaya pemasaran sebesar $\mathrm{Rp}$. 1.000 .000 maka volume penjualannya akan meningkat atau menurun sebesar Rp. 720.000.

\section{Pengujian Hipotesis}

Untuk menguji sejauhmana pengaruh biaya pemasaran dalam usaha meningkatkan penjualan
$\mathrm{Y}=\mathrm{a}+\mathrm{bx}$

Dimana nilai a dan $b$ dapat dicari dengan rumus sebagai berikut:

$$
a=\frac{\left(\sum Y\right)\left(\sum X^{2}\right)-\left(\sum X\right)\left(\sum X Y\right)}{n \sum X^{2}-\left(\sum X\right)^{2}}
$$

dapat dilakukan melalui langkah-langkah pengujian sebagai berikut:

$$
\begin{array}{r}
r=\frac{r \sqrt{n-2}}{\sqrt{1-r^{2}}} \\
r=\frac{0,93 \sqrt{5-2}}{\sqrt{1-0,93^{2}}} \\
r=\frac{0,93 \times 1,73}{0,37} \\
r=\frac{1,6089}{0,37} \\
r=4,35
\end{array}
$$

Dari hasil pengujian tingkat keyakinan dengan $\alpha=0,05$ dan $\mathrm{n}=5$ diperoleh 2,57 sedangkan $t_{\text {hitung }}$ 4,35. Keputusan tolak Ho karena $t_{\text {hitung }}$ lebih besar $t_{\text {tabel }}$ ini berarti bahwa pengaruh biaya pemasaran tehadap volume penjualan signifikan, karena hipotesis yang diajukan dapat diterima. Maksudnya kedua variabel mempunyai hubungan yang positif yaitu 0,93 dan pengaruh biaya pemasaran terhadap volume penjualan mempunyai pengaruh sebesar $86 \%$.

\section{KESIMPULAN}

1. Biaya pemasaran yang di keluarkan oleh perusahaan dari tahun 2011-2015 dengan total sebesar Rp 183.175.000.

2. Volume penjualan yang dikeluarkan oleh perusahaan dari tahun 2011-2015 dengan total sebesar Rp 184.975.000.

3. Berdasarkan hasil penghitungan didapat nilai:
a. Koefisien korelasi
: $\mathrm{r}=0.929$
b. Koefisien determinasi
: $\mathrm{KD}=86 \%$

Computer Science | Industrial Engineering | Mechanic Engineering |Civil Engineering 

c. Non determinasi
$:$ Non $\mathrm{D}=14 \%$
d. Regresi linear
$: \mathrm{Y}=$
$10787676.29+0.72 X$
e. Pengujlan hipotesis
$: \mathrm{t}=4.35$

4. Dengan demikian hipotesis penelitian dapat diterima, artinya biaya pemasaran berpengaruh positif terhadap volume penjualan.

\section{REFERENSI}

1984. Azas-Azas Marketing, Edisi Ketiga, Yogyakart

Basu, Swasta, 1990. Marketing, Ghalia Indonesia, Bandung.

B., Hecker, 1991. Controllership, Erlangga, Jakarta Joseph, P., Guiltman, 1994. Strategi dan Program Manajemen Pemasaran, Erlangga, Jakarta.

J, Supranto, 1997. tatistik Teori dan Aplikasi, Edisi Kelima, Erlangga, Jakarta.

J, William, 1999. Prinsip-Prinsip Pemasaran, Erlangga, Jakarta.

Khotler, Philip, dan Amstrong, G., (1997), Manajemen Pemasaran (Analisis Perencanaan, Implementasi, dan Kontrol), Jilid Dua, Prenhallindi, Jakarta.

Mulyadi, 1993. Akuntansi Manajemen Konsep Manfaat dan Rekayasa, STIE, Yogyakarta.

Stanton, J., William, 1994. Intisari Manajemen Pemasaran, Didasarkan oleh Saladin, J., IPTEK, Bandung. 